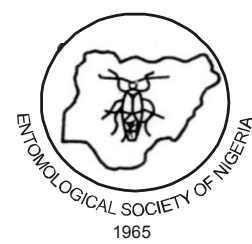

\title{
Effect of Sowing Dates, Intra-row Spacings and Pesticides on Maruca vitrata (Fab.) (Lepidoptera: Pyralidae) Damage on Cowpea in Samaru, Northern Guinea Savanna
}

\author{
Muhammad, A., ${ }^{1 *}$ Malgwi, A. M. ${ }^{2}$ and Nahunnaro, H. $^{2}$ \\ ${ }^{1}$ Department of Crop Production and Protection, Federal University Dutsin-ma, Katsina State \\ ${ }^{2}$ Department of Crop Protection, School of Agriculture and Agricultural Technology \\ Modibbo Adama University of Technology, Yola, Adamawa State, Nigeria
}

\begin{abstract}
A field trial was conducted during the 2015 and 2016 cropping seasons in Samaru northern Guinea savanna agro-ecological zone, at the Teaching and Research Farm, Institute for Agricultural Research, Ahmadu Bello University (IAR/ABU) Zaria, Nigeria. The objective of the research was to test the effect of sowing dates, intra-row spacings and biopesticides in the control of cowpea pod-borer, Maruca vitrata (Fabricius). The experiment was laid out in split-split plot design with sowing dates allocated to the main plot, intra-row spacings to the sub-plot and pesticides allocated to the sub-sub-plot. The treatments were randomized and replicated three times. Data collected on numbers of flower and pod damage were subjected to the analysis of variance and significant means were separated using LSD at 5\%. The result at 10 WAS showed that varying sowing dates significantly $(\mathrm{P} \leq .01)$ reduced percentage flower damaged by $M$. vitrata. Lower damage was recorded in SD3 (5.56, 5.00 and 5.28) while SD2 recorded the highest damage (11.94, 12.22 and 12.08) during 2015 and 2016 cropping season and the combine. The result of interaction of SD3 and MaviMNPV gave the least flower damage (5.00). MaviMNPV treated plots reduced percentage flower damage (7.04, 6.30 and 6.67) at $(\mathrm{P} \leq .05)$ but was not significantly better than NKE $(9.82,6.67$ and 8.24) and Cyper diforce (7.41, 10.74 and 9.07) which were statistically at par but lower than the control $(11.11,16.68$ and 13.89). The interaction of SD3 and Cyper diforce produce the least pod damage (6.67). Also delaying sowing date to SD3 was observed to significantly reduce percentage cowpea pod damage by $M$. vitrata at 10 WAS (15.28, 6.67 and 10.97) than the other SDs. Similarly, plots treated with Cyper diforce significantly $(\mathrm{P} \leq .01)$ observed lowest pod damage (15.37, 9.26 and 12.32) than NKE and MaviMNPV. The control recorded significantly higher pod damage in both years $(9.82,5.19$ and 7.50). Cyper diforce treated plots gave the highest yield of $394.56,887.69$ and $976.51 \mathrm{~kg} \mathrm{ha}^{-1}$ during 2015 and 2016 cropping seasons and combine but was statistically similar $(\mathrm{P} \leq .01)$ with NKE and MaviMNPV. The interaction of SD2 and Cyper diforce gave the highest grain yield (1673.45 $\left.\mathrm{kg} \mathrm{ha}^{-1}\right)$. The effect of sowing cowpea on 11th August (SD2) and Cyper diforce application will give a better control of $M$. vitrata for an increased yield of cowpea in the study area.
\end{abstract}

Keywords: Sowing dates, intra-row spacings, pesticides, damage, Maruca vitrata.

\section{INTRODUCTION}

Cowpea (Vigna unguiculata L. Walp.), is a dicotyledonous plant belonging to the family

*Correspondence author email:

amuhammad1@fudutsinma.edu.ng
Fabaceae. It is one of the most important crops in Africa cultivated by small scale farmers as a subsistence crop. The crop originated from Africa and spread through Egypt and domesticated in parts of Southern, Eastern and 
Western Africa where a large number of primitive cultivars and semi wild forms are found (Kwaifa et al., 2012). This grain legume is grown mainly in the savanna regions of the tropics and sub-tropics in Africa, Asia and South America (Singh et al., 1990; IITA, 2009). According to AATF (2011) cowpea is considered as the most important grain legumes in the dry savannas of tropical Africa, where it is grown on more than 12.8 million hectares of land. It is rich in quality protein and has energy content almost equivalent to that of cereal grain. The crop is a good source of quality fodder for livestock and provides cash income. The dried seeds of cowpea are a cheap dietary source of protein in many diets in the tropics and subtropics (Aliyu et al., 2007). It contains about $23-33 \%$ protein, $60-66 \%$, carbohydrates, $5-6 \%$, fibre, $3.4-3.7 \%$ ash and $1.1-3.0 \%$ oil (IITA, 2009). It is an important source of good quality fodder used in different parts of the tropics (AATF, 2011; Aliyu et al., 2007). Nearly, 200 million people of Africa consume the crop (AATF, 2014). The crop suffers much attack from insect pests. Losses in cowpea yield as reported by Ahmed et al. (2009) due to pests in northern Nigeria could be between $46-52 \%$ at flowering stage, $21-26 \%$ at pod formation, $7-9 \%$ at pre-flowering and $2-3 \%$ at the establishment stages. In general, losses due to pests attack or diseases can be as high as 90 percent (IITA, 2009). The legume pod borer, Maruca vitrata is one of the most important pests of grain legume throughout the tropics and sub-tropics of Central and South America, Asia and Africa (Agunbiade et al., 2012). Ogah, E. O. (2013) and Oyewale et al (2014) identified the borer among the three important grain legume pests as most important. These are the legume pod-borer, M. vitrata syn. Maruca testulalis; Heliothis armigera; and bean fly, Ophiomyia phaseolus. According to AATF (2011) M. vitrata is a major lepidopteran pest that causes severe damage to cowpea on farmers' field. In severe infestation, yield losses of between $70-80 \%$ have been reported.

The production of cowpea has continued to decline due to activities of wide spectra of insect pests, notably damage caused by $M$. vitrata. Severe infestation of the larva of this insect can reach up to $80 \%$ yield loss (AATF, 2011; Agunbiade et al., 2012). The use of synthetic chemicals in the management of postflowering insect pests is the practice carried out by most cowpea farmers nowadays. Spraying cowpea at 10 days interval (beginning at bud formation) give effective control of pod-borer (Sharma, 1998). However, excessive use of these chemicals has some associated problems often leading to general environmental contamination, elimination of economically beneficial insects as well as development of resistance by the pest (Immaraju et al., 1992). In addition, some of these insecticides are too expensive for small scale farmers as well as highly toxic to humans and animals (Sharma, 1998 and Asante et al., 2001). Farmers who have adopted control through chemical sprays are exposed to serious health hazards (Oyewale et al., 2014). Control of this pest is therefore, crucial for sustainable production of cowpea. Hence, there is need for sustainable and environmentally-friendly control strategies in order to reduce losses suffered by cowpea farmers. The objectives of the study were to determine the effect of sowing date, intra-row spacing and biopesticides on the damage and control of $M$. vitrata in Samaru, Nigeria.

\section{MATERIALS AND METHODS}

\section{Experimental Site}

A field trial was carried out in Samaru during the 2015 and 2016 cropping season. The trial was conducted at Teaching and Research Farm, Institute for Agricultural Research, Ahmadu Bello University (IAR/ABU), Zaria. The area 
lies on Latitude $11^{\circ} 10^{\prime} \mathrm{N}$ and Longitude $07^{\circ}$ $38^{\prime}$ E, 686m above sea level (Eneh and Ati, 2010). The area falls within northern Guinea savanna ecological zone. Zaria possesses a tropical continental climate with a pronounced dry season, lasting up to seven months (October-May). The rainy season lasts from May to September/October with long-term annual rainfall of $1040 \mathrm{~mm}$ in about 90 rain days.

\section{Cultural Practices}

The experimental site was ploughed, harrowed and ridged using tractor. Cowpea variety SAMPEA 7 (susceptible to $M$. vitrata infestation) was used. Allstar ${ }^{\circledR} 40$ SD a seed dressing chemical (20\% Metalaxyl $+20 \%$ limidacloprid) at the rate of one sachet per 4 $\mathrm{kg}$ of seeds was used to dress the seeds prior to planting against soil-borne diseases and insect pests (Oparaeke, 2005). Sowing was carried out at three weeks interval. Three cowpea seeds were sown per hole and later thinned to two seedlings per stand (Oparaeke et al., 2005). Single Super Phosphate fertilizer was applied at the rate of $25 \mathrm{~kg} \mathrm{P}_{2} \mathrm{O}_{5}$ a.i. ha ${ }^{-1}$ to each plot immediately after sowing. Mancozeb $80 \%$ (fungicide) as (Z-force) was applied at the rate of $0.33 \mathrm{~kg}$ a.i. ha ${ }^{-1}$ against fungal diseases when symptoms were observed. Weeding was carried out at 3 and 6 weeks after sowing (WAS) (Aghali, 1993). Gap filling was done at three weeks after germination to replace dead seedlings (Ogah, 2013).

\section{Sources and Preparation of Pesticides Neem Kernels Seed Extract (P1)}

Matured neem seeds were collected after rainfall in a neem tree forest reserve. The fruits were de-pulped, washed in a bucket containing clean water and air-dried in a well ventilated area. The seeds were cracked and the kernels removed and ground into powder using an electric kitchen blender (Model: DJ-BL242 manufactured by DAICHI Home essentials). About $5 \mathrm{~kg} \mathrm{ha}^{-1}$ of neem kernels seed powder together with $2 \mathrm{~kg} \mathrm{ha}^{-1}$ washing soap (bar soap) (emulsifier) were wrapped in a clean white cloth and soaked overnight in a bucket containing 100 litre ha ${ }^{-1}$ of water (Neem Foundation, 2005). The mixture was stirred thoroughly with a stirring rod and was squeezed until milky suspension was produced (Oparaeke, 2005; Oparaeke, 2006). Gum arabic was added at the rate of $2.7 \mathrm{~kg}$ in 6.75 litres of water ha $\mathrm{a}^{-1}$ as sticker (Kwaifa et al., 2012). This forms the crude extract.

\section{Maruca vitrata Multi-nucleopolyhedrosis virus (MaviMNPV) suspension (P2)}

The viral suspension was obtained from the International Institute of Tropical Agriculture (IITA), Cotonou, Benin Republic and was applied at the rate of $106 \mathrm{ml}+115$ litre water per hectare.

\section{Laboratory preparation of MaviMNPV}

According to Sokame et al (2015) freshly emerged third instar larvae of $M$. vitrata were inoculated with a virus suspension (from an initial inoculum obtained from The World Vegetable Center, AVRDC, Taiwan and continuously cultured at IITA-Benin) containing $2 \times 10^{6}$ occlusion bodies (OB)/larva. Artificial rearing diet was infused with the MaviMNPV formulation and fed to the larvae, leading to their subsequent infection and death. Virus-killed larvae were thoroughly macerated in distilled water and homogenized. The viral suspension was filtered through a sterilized muslin cloth, and the filtrate was centrifuged at for 5 mins. The supernatant was discarded and the sediment, containing the OB, was diluted with distilled water. The concentration of the viral suspension was determined by counting in a Neubauer haemocytometer. Serial 
dilutions were then made with distilled water to produce the concentration needed for the bioassay. Tween $80(0.25 \mathrm{ml})$ and glycerol $(0.5$ $\mathrm{ml}$ ) were added to each preparation to ensure adhesiveness of the solutions to the substrate.

\section{Cyper diforce (P3)}

A systemic, contact and stomach poison insecticide (30 $\mathrm{g} \mathrm{L}^{-1}$ Cypermethrin and $250 \mathrm{~g}$ $\mathrm{L}^{-1}$ Dimethoate EC) manufactured by Jubaili Agrotech was applied at the rate of $1.5 \mathrm{~L} \mathrm{ha}^{-1}$ using Knapsack CP-3 sprayer (Asante et al., 2001).

\section{Treatments and Experimental Design}

The treatments for the experiment consisted of three intra-row spacings, three sowing dates and three pesticides of which included two biopesticides, a synthetic check and a control. The experiment was carried out during the rainy seasons of 2015 and 2016. Split split plot design with factorial combination of intra-row spacings SP1; 75 x 20, SP2; 75 x 30 and SP3; $75 \times 40 \mathrm{~cm}$ allocated to the main plot, sowing dates SD1; 21/07/2015, SD2; 11/08/2015, SD3; $01 / 09 / 2015$ allocated to the sub plot, pesticides consisting of neem seeds kernel extract (NKE) (P1), Maruca vitrata Multi-nucleopolyhedrosis virus suspension (MaviMNPV) suspension (P2) and Cyper diforce (P3) and control (P0) were allocated to the sub-sub-plot. The treatments were randomized and replicated three times. Each plot consisted of six (6) ridges of $6 \mathrm{~m}$ long and $4.5 \mathrm{~m}$ wide. The ridges were separated by $0.75 \mathrm{~m}$ apart. The two middle rows (3rd and 4th) constituted the net plot (Kwaifa et al., 2012). The blocks were separated by a space of $2 \mathrm{~m}$ while $1 \mathrm{~m}$ was left between plots. A distance of $1 \mathrm{~m}$ was also left between main plots.

Field applications of neem seeds kernel extract and the insecticide was achieved using 2 separate 20 litre CP3 Knapsack sprayers. The viral suspension was applied using hand operated manual sprayer (model PUSHP 400). Treatments application commenced at 7 weeks after sowing (WAS) which coincided with the period of flower onset in the variety. Foliar spraying was done at 8.00 a.m. All the treatments were sprayed once every week for four weeks (Oparaeke et al., 2005).

\section{Data Collection}

Assessment of $M$. vitrata damage in flowers

Twenty flower buds or flowers depending on the stage of growth were randomly sampled from four stands per plot for assessment of $M$. vitrta damage $24 \mathrm{hrs}$ after treatment (Wudil et al., 2013). The flowers were placed in vials containing 30\% alcohol to allow dislodgement of larvae and were dissected using biceps the following day (Amatobi, 1994). The sampled flowers were assessed based on damage characteristics such as presence of entry/exit holes, dirty frass/excretes or life/dead larvae (Abdullahi and Ibrahim, 2014 and Asiwe et al., 2005).

\section{M. vitrata pod damage assessment}

Pod damage was achieved through destructive sampling. Twenty pods were examined for $M$. vitrata damage by randomly sampling five pods per plant from four stands per plot. The pods were placed in large envelopes for laboratory assessment. Pods damaged were assessed based on presence of entry/exit holes, frass deposition as well as presence of life or dead larva. Damaged pods were separated from the undamaged. Percentage pod damage was expressed as total number of damaged pods divided by the total number of pods harvested multiplied by 100 (Oghiakhe et al., 1991). Dried pod damage at harvest was assessed by separating the pods damaged due to $M$. vitrata from pods damaged due to complex of pod sucking bugs associated by shriveling, twisting, stunting and constriction (Ogah, 2013). 


\section{Assessment of yield}

Harvesting of dried cowpea pods was carried out when about $75 \%$ of the pods in the net plot dried. Subsequently, harvesting was carried out until all the pods were fully harvested. Plot yields were placed in large envelopes/polythene bags and adequately labelled. Borer damaged pods were separated, counted and considered as damaged by $M$. vitrata. Post harvest operations on the yield were carried out separately for each plot. The pods were threshed, winnowed and grains were weighed using Electronic Compact Scale, ATOM (A-110 model). Yield per plot was extrapolated to $\mathrm{kg}$ ha $^{-1}$ (Ahmed et al., 2009).

\section{Data Analysis}

Data obtained were subjected to analysis of variance (ANOVA) procedure. Prior to analysis, data with zero values were subjected to transformation using $\sqrt{n+0.5}$. Means with significant differences were separated using LSD at $\mathrm{P} \leq 0.05 \%$ level using SAS (2000) statistical package.

\section{RESULTS}

\section{Cowpea flower damaged by $M$. vitrata during 2015 and 2016 cropping seasons}

The result in Table 1 showed the effect of treatments on cowpea flower damage. Delay

Table 1: Effect of sowing dates, intra-row spacings and pesticides on post spray flower damage by Maruca vitrata in 20 flowers sampled 8, 9 and 10 (WAS) in Samaru during 2015 and 2016 cropping seasons

\begin{tabular}{|c|c|c|c|c|c|c|c|c|c|}
\hline \multicolumn{4}{|l|}{ Treatments } & \multicolumn{6}{|c|}{ Post sprays flower damage by $M$. vitrata } \\
\hline \multirow[t]{2}{*}{ Sowing dates } & \multicolumn{3}{|c|}{2015} & \multicolumn{3}{|c|}{2016} & \multicolumn{3}{|c|}{ Combined } \\
\hline & 8 WAS & 9 WAS & 10WAS & 8WAS & 9 WAS & 10WAS & 8WAS & 9 WAS & $10 \mathrm{WAS}$ \\
\hline SD1 & $16.53^{\mathrm{a}}$ & $15.28^{\mathrm{a}}$ & $9.03^{\mathrm{ab}}$ & $12.22^{\mathrm{b}}$ & $14.03^{\mathrm{b}}$ & $13.06^{\mathrm{a}}$ & $14.38^{\mathrm{b}}$ & $14.65^{\mathrm{a}}$ & $11.04^{\mathrm{a}}$ \\
\hline SD2 & $20.00^{\mathrm{a}}$ & $15.97^{\mathrm{a}}$ & $11.94^{\mathrm{a}}$ & $33.75^{\mathrm{a}}$ & $19.03^{\mathrm{a}}$ & $12.22^{\mathrm{a}}$ & $26.88^{\mathrm{a}}$ & $17.50^{\mathrm{a}}$ & $12.08^{\mathrm{a}}$ \\
\hline SD3 & $10.56^{\mathrm{a}}$ & $7.50^{\mathrm{b}}$ & $5.56^{\mathrm{b}}$ & $5.83^{\mathrm{b}}$ & $11.25^{\mathrm{b}}$ & $5.00^{\mathrm{b}}$ & $8.19^{\mathrm{b}}$ & $9.38^{\mathrm{b}}$ & $5.28^{\mathrm{b}}$ \\
\hline Mean & 15.69 & 12.92 & 8.84 & 17.27 & 14.77 & 10.09 & 16.48 & 13.84 & 9.47 \\
\hline LSD & 13.957 & 6.901 & 4.183 & 8.524 & 3.332 & 1.259 & 7.257 & 4.027 & 1.719 \\
\hline \multicolumn{10}{|l|}{ Intra-row spacing $(\mathrm{cm})(\mathrm{SP})$} \\
\hline SP1: $75 \times 20$ & 13.89 & $10.56^{\mathrm{b}}$ & 8.47 & 18.06 & 16.11 & 9.44 & 15.97 & 13.33 & 8.96 \\
\hline SP2: $75 \times 30$ & 14.03 & $13.47^{\mathrm{a}}$ & 9.31 & 17.78 & 15.00 & 11.53 & 15.90 & 14.24 & 10.42 \\
\hline SP3: $75 \times 40$ & 19.17 & $14.72^{\mathrm{a}}$ & 8.75 & 15.97 & 13.19 & 9.31 & 17.57 & 13.96 & 9.03 \\
\hline Mean & 15.69 & 12.92 & 8.84 & 17.27 & 14.77 & 10.09 & 16.48 & 13.84 & 9.47 \\
\hline LSD & 5.274 & 2.644 & 2.621 & 6.551 & 5.664 & 2.125 & 3.982 & 2.961 & 1.598 \\
\hline \multicolumn{10}{|l|}{ Pesticides $\quad(\mathrm{P})$} \\
\hline P1: Neem kernel extract & $14.44^{\mathrm{b}}$ & $13.15^{\mathrm{b}}$ & $9.82^{\mathrm{a}}$ & $13.70^{\mathrm{b}}$ & $10.19^{b}$ & $6.67^{\mathrm{c}}$ & $14.07^{\mathrm{b}}$ & $11.67^{\mathrm{b}}$ & $8.24^{\mathrm{b}}$ \\
\hline P2: MaviMNPV suspension & $12.04^{\mathrm{b}}$ & $10.56^{\mathrm{b}}$ & $7.04^{\mathrm{b}}$ & $12.59^{\mathrm{b}}$ & $12.78^{\mathrm{b}}$ & $6.30^{\mathrm{c}}$ & $12.32^{\mathrm{b}}$ & $11.67^{\mathrm{b}}$ & $6.67^{\mathrm{c}}$ \\
\hline P3: Cyper diforce & $12.96^{\mathrm{b}}$ & $11.11^{\mathrm{b}}$ & $7.41^{\mathrm{b}}$ & $11.48^{\mathrm{b}}$ & $10.56^{\mathrm{b}}$ & $10.74^{\mathrm{b}}$ & $12.22^{\mathrm{b}}$ & $10.83^{\mathrm{b}}$ & $9.07^{\mathrm{b}}$ \\
\hline P0: Control & $23.33^{\mathrm{a}}$ & $16.85^{\mathrm{a}}$ & $11.11^{\mathrm{a}}$ & $31.30^{\mathrm{a}}$ & $25.56^{\mathrm{a}}$ & $16.68^{\mathrm{a}}$ & $27.32^{\mathrm{a}}$ & $21.20^{\mathrm{a}}$ & $13.89^{\mathrm{a}}$ \\
\hline Mean & 15.69 & 12.92 & 8.84 & 17.27 & 14.77 & 10.09 & 16.48 & 13.84 & 9.47 \\
\hline LSD & 4.478 & 3.279 & 2.073 & 7.461 & 5.255 & 2.073 & 4.302 & 3.062 & 1.449 \\
\hline \multicolumn{10}{|l|}{ Interactions } \\
\hline $\mathrm{SD} \times \mathrm{SP}$ & NS & $*$ & NS & NS & NS & NS & NS & NS & NS \\
\hline $\mathrm{SD} \times \mathrm{P}$ & NS & NS & NS & $* *$ & NS & $* *$ & $* *$ & NS & $* *$ \\
\hline $\mathrm{SP} \times \mathrm{P}$ & NS & NS & $*$ & NS & NS & NS & NS & NS & $* *$ \\
\hline $\mathrm{SD} \times \mathrm{SP} \times \mathrm{P}$ & NS & NS & NS & NS & NS & NS & NS & NS & NS \\
\hline
\end{tabular}

Means with the same letter(s) in the same column are not significantly different using LSD at 5\% level, $\mathrm{NS}=$ Not significant, $*$ Significant at $\mathrm{P} \leq 0.05, * *$ Significant at $\mathrm{P} \leq 0.01$, WAS $=$ weeks after sowing, $\mathrm{SD}=$ Sowing dates, $\mathrm{SP}=$ Intra-row spacings, $\mathrm{P}=$ pesticides, SD1:21/07/2015 and 21/07/2016, SD2: 11/ 08/2015 and 11/08/2016, SD3 01/09/2015 and 01/09/2016. 
in sowing to $\mathrm{SD} 3$ significantly $(\mathrm{P} \leq 0.01)$ reduced flower damage compared to sowing in SD1 and SD2 which did not differ significantly from each other in 2015. However, higher percentage flower damage was obtained in SD2 in all the periods of sampling. The highest was obtained at SD2 (33.75) at 8 WAS in 2016 and SD3 recorded significantly lowest damage (5.00) at 10 WAS. Significantly higher numbers of flowers were damaged in the control compared with the different pesticides which recorded minimal flower damage. However, there was no significant difference between the various pesticides (NKE, MaviMNPV and Cyper diforce at 8 and 9 weeks after sowing (Table 1). However, MaviMNPV was most effective although not significantly different with NKE in reducing flower damage (6.30) at 10 WAS in 2016.

The result of the interaction between sowing dates and pesticides at 10 WAS during 2015 and 2016 cropping seasons in reducing flower damage (Table 2). The result showed high significant interaction effect between sowing dates and use of pesticides. Varying sowing dates from SD2 to SD3 significantly reduced mean flower damaged by $M$. vitrata except at SD3 which was significantly different in 2015. Similarly, high significant $(\mathrm{P} \leq 0.01)$ interaction was observed on the use of pesticides compared with the control in reducing flower damage in all the sowing dates except at SD3 in which they were statistically similar. Plots treated with MaviMNPV recorded significantly lowest mean flower damage in all the three sowing dates except at SD3. High interaction effect was observed by MaviMNPV at SD3 which recorded the lowest flower damage (5.83) but was not differ significantly $(\mathrm{P} \leq 0.05)$ with NKE (5.83) and Cyper diforce (5.83). The lowest effect was obtained by the interacting effect of control at SD1 (17.78) but was statistically same with control at SD2 (17.78).
Table 2: Result of combined interaction between sowing dates and pesticides on post spray flower damaged by $M$. vitrata at 10 WAS during 2015 and 2016 cropping season in Samaru

\begin{tabular}{lllll}
\hline \multicolumn{5}{c}{ Biopesticides } \\
& P0 & P1 & P2 & P3 \\
\hline SP 1 & $12.78^{\mathrm{a}}$ & $7.50^{\mathrm{bc}}$ & $8.33^{\mathrm{bc}}$ & $7.22 \mathrm{~b}^{\mathrm{c}}$ \\
SP 2 & $14.72^{\mathrm{a}}$ & $8.89^{\mathrm{b}}$ & $5.83^{\mathrm{c}}$ & $12.22^{\mathrm{a}}$ \\
SP 3 & $14.17^{\mathrm{a}}$ & $8.33^{\mathrm{bc}}$ & $5.83^{\mathrm{c}}$ & $7.78^{\mathrm{bc}}$ \\
LSD & 2.534 & & & \\
\hline
\end{tabular}

Key: SP1 $=75 \times 20 \mathrm{~cm}, \mathrm{SP} 2=75 \times 30 \mathrm{~cm}, \mathrm{SP} 3=75 \times$ $40 \mathrm{~cm}, \mathrm{P} 0=$ control, $\mathrm{P} 1=$ Neem seeds kernel extract, P2 = MaviMNPV suspension, P3 = Cyper diforce, SD $=$ sowing dates, $\mathrm{SD}=$ sowing date, $\mathrm{SD} 1: 21 / 07 / 2015$ and $21 / 07 / 2016$, SD2: 11/08/2015 and 11/08/2016, SD3 $01 / 09 / 2015$ and $01 / 09 / 2016$

\section{Percentage cowpea pod damaged by $M$. vitrata during 2015 and 2016 cropping seasons}

The result obtained indicated that varying sowing dates from SD1 to SD2 did not have any significant effect on percentage cowpea pod damage at 10 WAS. However, SD2 recorded the highest pod damage (28.06) except in 2015 in which SD1 recorded the highest (35.28). Further delay in sowing to SD3 significantly $(\mathrm{P} \leq 0.01)$ reduced pod damage (Table 3$)$. Cyper diforce was most effective in reducing cowpea pod damage in all the years and the combined. However, its effectiveness was not significantly different with MaviMNPV and NKE. The control significantly recorded higher cowpea pod damage (31.94) at 10 WAS in all the years and the combine (Table 3 ). The result of combine interaction of varying sowing dates significantly reduced percentage cowpea pod damage by $M$. vitrata at 10 WAS (Table 4). Significantly higher pod damage was obtained in SD2 in all the pesticides treated plots and even with the control better than SD3 which recorded the least pod damage. Plots treated with Cyper diforce were observed to record the least pod damage. However, its effectiveness 
did not differ significantly from NKE and MaviMNPV in all the sowing dates. Highest interaction effect was observed by Cyper diforce treated plots at SD3 (6.67) and the lowest effect was by the interacting control and SD2 (42.22).

Table 3: Effect of sowing dates, intra-row spacings and pesticides on percentage cowpea pod damage by M. vitrata sampled 10 WAS during 2015 and 2016 cropping seasons in Samaru

\begin{tabular}{llll}
\hline Treatments & 2015 & 2016 & Combined \\
\hline Sowing dates & & & \\
SD1 & & & \\
SD2 & $35.28^{\mathrm{a}}$ & $5.56^{\mathrm{b}}$ & $20.42^{\mathrm{a}}$ \\
SD3 & $28.06^{\mathrm{a}}$ & $22.22^{\mathrm{a}}$ & $25.14^{\mathrm{a}}$ \\
Mean & $15.28^{\mathrm{b}}$ & $6.67^{\mathrm{b}}$ & $10.97^{\mathrm{b}}$ \\
LSD & 26.20 & 11.48 & 18.84 \\
Intra-row spacing (cm) (SP) & 11.573 & 13.12 & 2.947 \\
SP1: 75 x 20 & & & \\
SP2: 75 x 30 & 26.67 & $13.89^{\mathrm{a}}$ & 20.28 \\
SP3: 75 x 40 & 26.53 & $10.97^{\mathrm{b}}$ & 18.75 \\
Mean & 25.42 & $9.58^{\mathrm{b}}$ & 17.50 \\
LSD & 26.20 & 11.48 & 18.84 \\
Biopesticides & 7.129 & 2.729 & 1.826 \\
P1: Neem kernels extract & & & \\
P2: MaviMNPV suspension & $22.96^{\mathrm{b}}$ & $10.19^{\mathrm{b}}$ & $16.57^{\mathrm{b}}$ \\
P3: Cyper diforce & $19.26^{\mathrm{bc}}$ & $9.82^{\mathrm{b}}$ & $14.54^{\mathrm{bc}}$ \\
P0: Control & $15.37^{\mathrm{c}}$ & $9.26^{\mathrm{b}}$ & $12.32^{\mathrm{c}}$ \\
Mean & $47.22^{\mathrm{a}}$ & $16.67^{\mathrm{a}}$ & $31.94^{\mathrm{a}}$ \\
LSD & 26.20 & 11.48 & 18.84 \\
Interactions & 5.490 & 3.756 & 1.818 \\
SD x SP & & & \\
SD x B & $\mathrm{NS}$ & $\mathrm{NS}$ & $\mathrm{NS}$ \\
SP x B & $*$ & $*$ & $*$ \\
SD x SP x B & $\mathrm{NS}$ & $\mathrm{NS}$ & $\mathrm{NS}$ \\
\hline
\end{tabular}

Means with the same letter(s) within the same column are not significantly different using LSD at 5\% level, $\mathrm{NS}=$ Not significant, $*=$ Significant at $\mathrm{P} \leq 0.05, * *=$ Significant at $\mathrm{P} \leq 0.01, \mathrm{SD}=$ Sowing dates, $\mathrm{SP}=$ Intra-row spacings, $\mathrm{P}=$ Pesticides, SD1:21/07/2015 and 21/07/2016, SD2: 11/08/2015 and 11/08/ 2016, SD3 01/09/2015 and 01/09/2016.

Total Cowpea Grain Weight during 2015 and 2016 Cropping Seasons

The result presented in Table 5 indicated that, varying sowing dates from SD1 to SD2 significantly $(\mathrm{P} \leq .01)$ increased grain weight in all the years and the combined. Further delay to SD3 although statistically similar but reduced total grain seed weight. The highest yield was obtained in SD2 (337.85, 689.10 and $\left.800.66 \mathrm{~kg} \mathrm{ha}^{-1}\right)$ and the least was obtained in SD1 (112.32, 323.50 and $313.39 \mathrm{~kg} \mathrm{ha}^{-1}$ ) during 2015, 2016 and the combined. The result is presented in Figure 1.Varying intra-row spacing resulted in to statistically similar yield between SP1 (524.99 $\left.\mathrm{kg} \mathrm{ha}^{-1}\right)$ and SP3 (577.48 $\mathrm{kg} \mathrm{ha}^{-1}$ ) during 2015 and 2016 cropping seasons. Significantly $(\mathrm{P} \leq 0.05)$ higher grain seed weight was obtained in SP2 $(651.26 \mathrm{~kg}$ 
Table 4: Result of combined interaction between sowing date and pesticides on percentage cowpea pod damaged by $M$. vitrata at 10 WAS during 2015 and 2016 cropping season in Samaru

\begin{tabular}{lllll}
\hline \multicolumn{5}{c}{ Biopesticides } \\
& P0 & P1 & P2 & P3 \\
\hline SD 1 & $35.00^{\mathrm{b}}$ & $16.94^{\mathrm{d}}$ & $15.00^{\mathrm{de}}$ & $14.72^{\mathrm{de}}$ \\
SD 2 & $42.22^{\mathrm{a}}$ & $23.05^{\mathrm{c}}$ & $19.72^{\mathrm{cd}}$ & $15.56^{\mathrm{d}}$ \\
SD 3 & $18.61^{\text {cd }}$ & $9.72^{\mathrm{e}}$ & $8.89^{\mathrm{e}}$ & $6.67^{\mathrm{e}}$ \\
LSD & & & & \\
\hline
\end{tabular}

Key: $\mathrm{P} 0=$ control, $\mathrm{P} 1=$ Neem seeds kernel extract, P2 = MaviMNPV suspension, P3 = Cyper diforce, SD = sowing dates, SD1:21/07/2015 and 21/07/ 2016, SD2: 11/08/2015 and 11/08/2016, SD3 01/ $09 / 2015$ and $01 / 09 / 2016$

$\left.\mathrm{ha}^{-1}\right)$. Cyper diforce significantly $(\mathrm{P} \leq 0.01)$ recorded higher grain yield in the two years and combined (394.56, 887.69 and $976.51 \mathrm{~kg}$ $\mathrm{ha}^{-1}$ ). The yield obtained in NKE (178.19, 424.92 and $453.03 \mathrm{~kg} \mathrm{ha}^{-1}$ ) and MaviMNPV (188.26, 417.88 and $463.07 \mathrm{~kg} \mathrm{ha}^{-1}$ ) did not differ significantly. The lowest yield was obtained in the control $(165.70,243.92$ and $\left.445.69 \mathrm{~kg} \mathrm{ha}^{-1}\right)$.

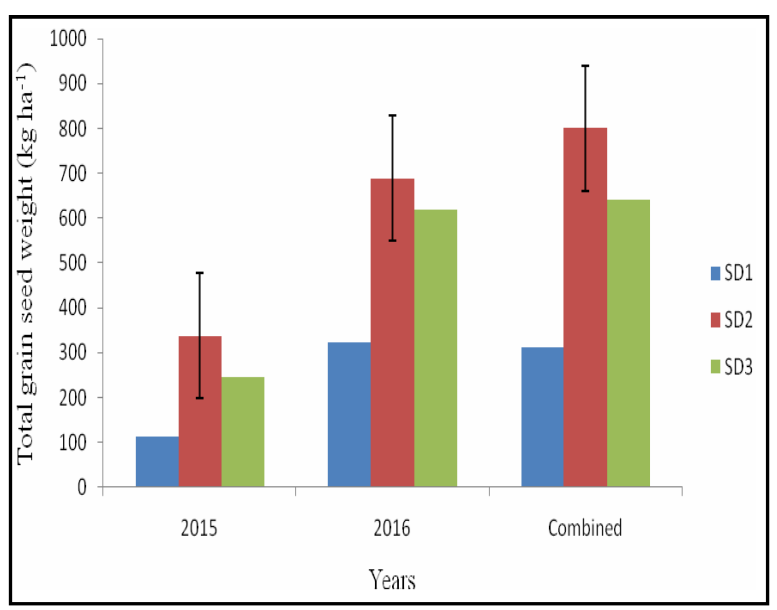

Fig. 1: Total cowpea grain seed weight $\left(\mathrm{kg} \mathrm{ha}^{-1}\right)$ during 2015 and 2016 cropping seasons, SD1:02/ 07/2015 and 02/07/2016, SD2: 23/07/2015 and 23/ 07/2016, SD3: $13 / 08 / 2015$ and 13/08/2016
Table 5: Effect of sowing dates, intra-row spacings and pesticides on total cowpea grain weight during 2015 and 2016 cropping season in Samaru $\left(\mathrm{kg} \mathrm{ha}^{-1}\right)$

\begin{tabular}{llll}
\hline Treatments & 2015 & 2016 & Combined \\
\hline Intra-row spacing (cm) (SP) & & & \\
SP1: 75 x 20 & 199.90 & 510.24 & $524.99^{\mathrm{b}}$ \\
SP2: 75 x 30 & 272.88 & 565.74 & $651.26^{\mathrm{a}}$ \\
SP3: 75 x 40 & 222.27 & 554.84 & $577.48^{\mathrm{ab}}$ \\
Mean & 231.68 & 543.61 & 584.58 \\
LSD & 69.165 & 143.740 & 117.950 \\
Biopesticides & & & \\
P1: Neem kernels extract & $178.19^{\mathrm{b}}$ & $424.92^{\mathrm{b}}$ & $453.03^{\mathrm{b}}$ \\
P2: MaviMNPV suspension & $188.26^{\mathrm{b}}$ & $417.88^{\mathrm{b}}$ & $463.07^{\mathrm{b}}$ \\
P3: Cyper diforce & $394.56^{\mathrm{a}}$ & $887.69^{\mathrm{a}}$ & $976.51^{\mathrm{a}}$ \\
P0: Control & $165.70^{\mathrm{b}}$ & $243.94^{\mathrm{c}}$ & $445.69^{\mathrm{b}}$ \\
Mean & 231.68 & 543.61 & 584.58 \\
LSD & 79.976 & 117.410 & 121.670 \\
Interactions & & & \\
SD x SP & NS & NS & NS \\
SD x B & $* *$ & $* *$ & $* *$ \\
SP x B & NS & NS & NS \\
SD x SP x B & NS & NS & NS \\
\hline
\end{tabular}

Means with the same letter(s) within the same column are not significantly different using LSD at $5 \%$ level, NS $=$ Not significant, $*=$ Significant at Pd"0.05, ** = Significant at Pd"0.01, SD = Sowing dates, $\mathrm{SP}=$ Intra-row spacings, $\mathrm{P}=$ Pesticides

\section{DISCUSSION}

The effect of varying intra-row spacings showed that there was no significant difference in flowers damaged by $M$. vitrata between SP1 and SP2. Close spacing however recorded lower flower damage. This finding is similar to the observation of Rauf and Sandar (2011) who reported that crude extract of neem upon application on bean plants has been shown to result in significant reduction in flower damage when compared with the control. NKE, Cyper diforce and MaviMNPV performed better than the control in reducing flower damage 24 hours after treatment. Significantly higher flower damage was recorded in the control plots. This result is in consonance with the findings of Degri et al (2012); Oparaeke (2006); Oparaeke et al (2006) that reported insecticidal properties 
of plant extracts and synthetic insecticides on cowpea pests. Several authors have shown the efficacy of different plant materials as biopesticides for the control of different pest of cowpea (Panhwar, 2002).

The result of this study showed that early sowing of cowpea (SD1) recorded significantly $(\mathrm{P} \leq 0.01)$ higher pod damage by $M$. vitrata in cowpea sampled 10 WAS. However, lower pod damage was observed in SD3 than in SD2. This could be attributed to the fact that early sown cowpea flowering and pod formation stages coincided with the period of high population densities of $M$. vitrata due to favourable breeding conditions that could lead to high infestations. The result of the effect of varying intra-row spacings indicated no significant difference in all the locations studied. This result is in agreement with the findings of Ajao et al (2016) who in study carried out in Abeokuta reported no significant effect of plant spacing on the number insect pests as well as pod damage on cowpea. Also, this finding is similar to the results obtained by Yusuf and Zakari (2016) in a trial conducted in Kano showed that spacing had no significant effect $(\mathrm{P}>0.05)$ on population of insect pests on cowpea. No significant difference was observed between NKE and MaviMNPV, but the viral suspension was found to reduce population of M. vitrata in cowpea pods better than NKE. Cyper diforce was significantly (Pd"0.01) most effective in reducing pod damage 10 WAS. The performance of MaviMNPV compared with Cyper diforce showed that the viral suspension is a potential biopesticides which could be use as an alternative to synthetic insecticide.

Varying intra-row spacings had no significant effect on cowpea total grain yield as obtained in this study. This result was similar to the findings of Yusuf and Zakari (2016) that observed that spacing had no significant effect on cowpea yield components in Kano. Cowpea sown in mid-August (11th August) (SD2) significantly performed better than early sown (21st July) (SD1). However, cowpea sown in SD3 did not differ significantly from cowpea sown in early September (SD3). The reason due to poor performance of early sown cowpea could be attributed due to heavy insects attacked that were observed. The low yield obtained in cowpea sown in mid-August (SD2) was $27.53 \%$ higher than late July (SD1) and early September sown cowpea (SD3). The result obtained in this study pointed to the fact that among the three treatments, higher cowpea grain yield was obtained from Cyper diforce treated plots compared with MaviMNPV and NKE which were statistically similar with the control. MaviMNPV performance on grain yield was poor compared with Cyper diforce. However, its potency could be improved if applied in synergy with another control agent. This is in consonance with the work of Sokame et al (2015). The toxicity conferred by Cyper diforce was superior to that of other treatments in protecting cowpea thereby increasing yield compared with the control. The result obtained is in agreement with Tanzubil (2000) who reported insecticide application in protecting crops against insect damage increased yield several folds. This finding concurred with the report that application of insecticides generally reduce cowpea pest infestations and markedly increase crop yield (Karungi et al., 2000; Ebenezer, 2010). Therefore, the high level of pod insect pests could lead to total loss of the crop, especially where there is little or no rain to trigger new flush or re-growth (Oyewale et al., 2014).

\section{RECOMMENDATION}

Using the viral suspension alone in this trial did not confer effective control as obtained in this study. However, its potency could be improved when used in combination with another control agent. 


\section{ACKNOWLEDGEMENT}

We thank the contributions of Dr. M. Tamo and his co-workers for providing the viral formulation used in this research.

\section{REFERENCES}

African Agricultural Technology Foundation (AATF) (2011). Pod-borer resistant cowpea Project, www.aatf-africa, retrieved 18/01/ 2014.

African Agricultural Technology Foundation AATF) (2014). Pod-borer resistant cowpea project partnership- developing a pod-borer resistant cowpea. www.aatf-africa.org

Abdullahi, M. M. and Ibrahim, S. K. (2014).Assessment of the effect of time, synthetic and botanical insecticides spray regimes on the abundance of predators in cowpea production in Kebbi State of Nigeria. IOSR Journal of Agriculture and Veterinary Sciences, 7(5), 87-95.

Agunbiade, T. A., Coates, B. S., Kim, K. S., Forgacs, D., Margam, V. M., Murdock, L. L., et al (2012). The spatial genetic differentiation of the legume pod-borer, Maruca vitrata F. (Lepidoptera: Crambidae) populations in West Africa. Bulletin of Entomological Research, 1-11.

Ahmed, B. I., Onu, I. and Mudi, L. (2009). Field bioefficacy of plant extracts for the control of post flowering insect pests of cowpea, Vigna unguiculata (L.) Walp. in Nigeria. Journal of Biopesticides. 2(1): 37-43.

Ajao, F. O., Osipita, A. A. and Lawal, O. I. (2016). Effect of plant spacing on abundance of major insect pests of cowpea, (Vigna unguiculata (L.) Walp.) and crop yield. [Abstract] Journal of Organic Agriculture and Environment, 4(1):

Alghali, A. M. (1993). Intercropping as a component in insect pest management for grain cowpea, Vigna unguiculata (Walp) production in Nigeria. Journal of Tropical Insect Science, 14(1): 50-52.

Aliyu, M,. Ladan, T., Ahmed, B.I. and Abdullahi, J. (2007). Studies on the efficacy of black soap and kerosene on the control of pod sucking bugs (Clavigralla tomentosicollis Stal.) on Cowpea (Vigna unguiculata (L.) Walp.). Emirate Journal Food Agriculture, 19(2): 08-12.

Amatobi, C.I. (1994). Field evaluation of some insecticides for the control of insect pest of Cowpea, Vigna unguiculata (L.) Walp.in Sudan savanna of Nigeria. International Journal of Pest Management, 40, 13-17.

Asante, S. K., Tamo, M., and Jackai, L.E.N. (2001). Integrated management of cowpea insect pests using elite cultivars, date of planting and minimum insecticide application. African Crop Science Journal, 9(4), 655-665.

Asiwe, J. A. N., Nokoe, S. Jackai, L. E. N. and Ewete, F. K. (2005). Does varying cowpea spacing provide better protection against cowpea pests. Crop Protection, 24(5), 465-471.

Degri, M. M., Maina, Y. T. and Richard, B. I. (2012). Effect of plant extracts on post flowering insect pests and grain yield of cowpea (Vigna Unguiculata) (L.) Walp.) in Maiduguri, semi arid zone of Nigeria Journal of Biology, Agriculture and Healthcare 2(3), 46-51. ISSN 2224-3208 (Paper) ISSN 2225093X (Online).

Ebenezer, O. O. (2010). Management of major field pests and yield of cowpea (Vigna unguiculata (L) Walp) under calendar and monitored application of synthetic chemicals in Asaba, Southern Nigeria. African journal General Agriculture, 6(3): 177-186.

Eneh, A. E.O. and Ati, O. F. (2010). The influence of rainfall on Hausa traditional architecture. Research Journal of Applied Sciences, Engineering and Technology, 2(8): 695-702.

International Institute of Tropical Agriculture (IITA) (2009). Cowpea, Vigna unguiculata. CGIAR. www.iita.org. Retrieved 15/04/2014.

Immaraju, J. A., Paine, T. O. Bethke, J. A. and Robb, K. L. (1992). (Thysanoptera: Thripidae)Resistance to insecticides in coastal California greenhouses. Journal of Economic Entomology, 85: 9-14. 
Karungi, J., Adipala, E., Kyamanywa, S., Ogenga-Latigo, M. W. and Obuo, J. E. (2000). Pest management in cowpea. Part 2. Influence of time and frequency of insecticide application on cowpea field insect pests infestation in eastern Uganda. Crop Protection (in press).

Kwaifa, N. M., Ibrahim, N. D., Dike, M. C. and Abubakar, M. G. (2012). Bioefficacy of neem and mahogany extracts for control of cowpea flower Thrips, Megaluthrips sjostedti Trybom [Thysanoptera: Thripididae] and Grasshopper, Ailopus simulatrix Walker [Orthoptera: Pyrgomorphidae] in Sudan savannah, Nigeria. Nigerian Journal of Entomology, 29: 31-42.

Neem Foundation (2005). Spreading the neem revolution. an informal compilation of some of the investigations and developments done on neem in the recent pasts. Neem Foundation. www.neemfoundation.org/ invest.htm. Retrieved on 07/01/2005.

Ogah, E. O. (2013). Field evaluation of plant extracts in the management of Megalurothrips sjostedti and Maruca vitrata of cowpea in Southeastern Nigeria. World Essays Journal, 1(1), 11-17. Available online at www.worldessaysj.com

Oghiakhe, S., Jackai, L. E. N. and Makanjuola, W. A. (1991). Cowpea plant architecture in relation to infestation and damage by the legume pod borer Maruca testulalis Geyer (Lepidoptera: Pyralidae)-1 effect of canopy structure and pod position. Insect Science Application, 12(1/2/3): 193-199.

Oparaeke, A. M. (2005). Studies on the insecticidal potential of extracts of Gmelina arborea products for control of field pests of cowpea, Vigna unguiculata (L.) Walp and Clavigralla tomentosicollis. Journal of Plant Protection Research, 45(1): 1-7.

Oparaeke, A. M. (2006). Effect of aqueous extract of Tropical plants for management of Maruca vitrata Fab. and Clavigralla tomentosicollis Stal. on Cowpea, Vigna unguiculata (L.) Walp. plants. Journal of Entomology, 3(1): 70-75.
Oparaeke, A. M., Dike, M. C. and Amatobi, C. I. (2005). Evaluation of botanical mixtures for insect pests management on cowpea plants. Journal of Agriculture and Rural Development in the Tropics and Subtropics, 106(1): 41-48.

Oparaeke, A. M., Dike, M. C. and Amotobi, C. I. (2006). Field evaluation of an extract of five Nigerian spices for control of post flowering insect pests of cowpea, Vigna unguiculata (L.) Walp. Plant Protection Sciences, 41: 14-20.

Oyewale, R. O., Bamaiyi, L. J., Oparaeke, A. M. and Adamu, R. S. (2014). Evaluation of four insecticide formulations for the management of insect pests of cowpea. African Journal of Food Science and Technology, 5(8): 180-188. DOI: http:/ dx.doi.org/10.14303/ajfst.2014.101. Retrieved on 13/07/2016.

Panhwar, S. B. (2002). Farmers adoption of plant materials for insect control. International Service for Agricultural Research, Haque, Netherlands 4, 61-68.

Rauf, F. M. A. and Sardar, A. (2011). Effect of crude seed extract of some indigenous plants for the control of legume pod borer (Maruca vitrata F.) on country bean. Bangladesh Journal of Agriculture and Natural Resources, 36(1): 41-50.

SAS (2000). SAS Users Guide; version 606, Cary, NC: SAS Institute.

Sharma, H. C. (1998). Bionomics, host plant resistance, and management of the legume podborer, Maruca vitrata - a review. Crop Protection, 17(5): 373-376.

Singh, S. R., Jackai, L. E. N., Dos SANTOS, J. H. R. and Adalla , C. B. (1990). Insect pests of cowpea. In: Singh, S.R. (ed.) Insect pests of food legumes. New York, John Wiley \& Sons.

Sokamè, B. M., Tounou, A. K., Datinon, B., Dannon, E. A., Agboton, C., Srinivasan, R., Pittendrigh, B. R. and Tamò M. (2015). Combined activity of Maruca vitrata multinucleopolyhedrovirus MaviMNPV), and oil from neem, Azadirachta indica Juss and 
Jatropha curcas L., for the control of cowpea pests. Crop Protection, 72: 150-157.

Tanzubil, P. B. (2000). The control of insect pests of cowpea (Vigna unguiculata (L.) Walp) with neem (Azadirachta indica) in Northern Ghana. Tropical Pest Management,37(3): 216-217.

Yusuf, A. U. and Zakari, F. S. (2016). Influence of plant spacing on insect pest infestation and yield of some Cowpea (Vigna unguiculata L.
Walp.) varieties in Kano, Nigeria. [Abstract]. Journal of Organic Agriculture and Environment, 4(1).

Wudil, B. S., Ahmed, B. I. and Yusuf, S. R. (2013). Field evaluation of two essential oils and a synthetic insecticides for the control of some major insect pests of Cowpea (Vigna unguiculata (L.) Walp in Bauchi State, Nigeria. Nigerian Journal of Entomology, 30: 114-135.
Nigeria Journal of Entomology

Published by the Entomological Society of Nigeria

www.esnjournal.com.ng

ISSN: 0331-0094

Vol. 34, 2018; pp. 87-98

DOI: $10.36180 / N J E / 8102 / 43(0101)$

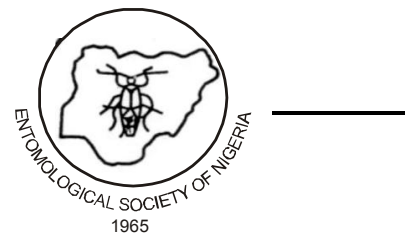

